\title{
Comparison of meat quality in young Black-and-White breed bulls and their hybrids with beef breeds
}

\section{Groth, Zofia Wielgosz-Groth, Z. Kijak, Janina Pogorzelska and M. Wroński}

\author{
Department of Cattle Breeding, \\ Olsztyn University of Agriculture and Technology \\ Oczapowskiego 5, 10-718 Olsztyn, Poland
}

(Received 1 April 1998; accepted 19 March 1998)

\begin{abstract}
Meat quality was assessed in 3 groups of young $F$, hybrids after Black-and-White cows with 12.5-50\% of Holstein-Fresian blood, and after beef bull varieties: Belgian Blue (BW x BB), 25 animals; Charolaise (BW x Ch), 9 animals; and Angus (BW x A), 8 animals, and compared to meat quality in Black-and-White bulls (BW) of the same age, 9 animals. Fattening lasted from the 6 th till the 20 th month of life. Bulls of semi-intensive group feeding received the rations composed of maize silage, given ad libitum, $1 \mathrm{~kg}$ of meadow hay and $1-2 \mathrm{~kg}$ concentrate, ensuring daily gains of about $800 \mathrm{~g}$. Meat quality was assessed in samples collected from the $M$. longissimus dorsi (LD) and $M$. semitendinosus (SM). Physico-chemical and sensoric parameters were determined as was the chemical composition of the meat. It was found that meat quality was affected by the bull genotype, and in some cases also by the type of muscles from which the samples were collected. Overall analysis of meat quality does not allow an unequivocal statement to be made on which group of animals gave meat most suitable for cooking. Nevertheless, sensoric evaluation favoured meat of the crossbreeds of Black-and-White and Belgian Blue.
\end{abstract}

KEY WORDS: young bulls, crossbreeds, meat quality

\section{INTRODUCTION}

In order to improve meat cattle production in Poland and to find suitable markets for these products, it is necessary to pay more attention to meat quality, especially to quality parameters important in cooking. These parameters are to a large extent related to heritable traits of fattening animals (Wichłacz and Trela, 1996), i.e. to 
their type, breed and variety. The most common method used is to improve beef quality by crossing local cattle with beef breeds. Fattening purely beef breeds is quite rare due to insufficient numbers of these animals in Poland.

Belgian Blue cattle is one of the youngest beef breeds obtained in the last thirty years; it is characterized by especially high qualities with respect to meat use. The results of studies carried out in other countries suggest that meat quality of Belgian Blue bulls and their crossbreeds is higher than of other beef breeds and their crosses with dairy breeds (Clinquart et al., 1994; Gerhardy, 1994; Schneijdenberg et al., 1994; Homer et al., 1997).

Due to different breeding conditions and genotypic divergence of Black-andWhite cattle in Poland, it was decided to compare meat quality of young bulls, crossbreeds of Black-and-White with Belgian Blue, Charolaise and Angus breeds, and of Black-and-White bulls.

\section{MATERIAL AND METHODS}

Meat quality was analyzed in 3 groups of young bulls, $F$, hybrids after Blackand-White (BW) cows having 12.5-50\% Holstein-Fresian blood and bulls of beef breeds: Belgian Blue (BW x BB), 25 animals; Charolaise (BW x Ch), 9 animals; and Angus (BW x A), 8 animals. The results were compared to Black-and-White (BW) bulls of the same age, 9 animals. Cows inseminated with the semen of beef breeds were in the 4.9 lactation on average; they were in good condition (3.9 points on a 5-point scale) with an average body weight of $590 \mathrm{~kg}$. Each group comprised animals from 3-5 sires. The age difference of the young bulls did not exceed 2 months. Fattening lasted from 6 to 20 month of age and was carried out in 2 farms. One farm was engaged in fattening Black-and-White bulls, all crosses with Charolaise and Angus, and 12 hybrids with Belgian Blue breed. The other hybrids, $\mathrm{BW} \times \mathrm{BB}$ were fattened on the other farm. In both farms the bulls were given the same ration and kept in a stanchion barn. A semi-intensive feeding system was applied, composed of maize silage, $1 \mathrm{~kg}$ of meadow hay, and concentrates, assuming that this ration would ensure daily weight gains of about $800 \mathrm{~g}$. Silage was given ad libitum; $1 \mathrm{~kg}$ contained $1.2 \mathrm{MJ}$ metabolizable energy and $21 \mathrm{~g}$ of crude protein, while meadow hay had $3.3 \mathrm{MJ}$ metabolizable energy and $82 \mathrm{~g}$ of crude protein. Doses of the concentrates were established according to the mean body weight of the animals in each group, the amounts used being 1-2 kg daily per bull. Mean bull weights were determined by weighing the animals at monthly intervals. This feeding resulted in the following final weight of bulls aged 20 months: BW $\times$ BB $-532 \mathrm{~kg}, \mathrm{BW} \times \mathrm{Ch}-517 \mathrm{~kg}, \mathrm{BW} \times \mathrm{A}-488 \mathrm{~kg}$ and $\mathrm{BW}-452 \mathrm{~kg}$. The average daily weight gains calculated for the whole fattening period ranged from $640 \mathrm{~g}$ in the control group to $767 \mathrm{~g}$ in BW x Ch hybrids. At the end of the fattening period all 
animals were starved for one day and then slaughtered. The carcasses were cooled at $2^{\circ} \mathrm{C}( \pm 0.2)$ for $24 \mathrm{~h}$ and samples of the $M$. longissimus dorsi (LD) and the $M$. semitendinosus (SM) were collected from the right half of the carcass.

The following physico-chemical parameters were determined in meat samples: colour on an eight-point scale, colour lightness by spectrophotometry, $\mathrm{pH}$ value $48 \mathrm{~h}$ after slaughter, marbling on a 5-point scale, cutting force measured using an Instrom 4501 with a Werner-Bratzler supply. Water absorption was measured by two methods, after Janicki, and Grau and Hamm (Znaniecki, 1983), thermal drip according to Janicki and Walczak (Znaniecki, 1983), and thermal shrinkage from the difference in weight before and after thermal processing. Dry matter, crude fat, crude protein, and soluble protein contents in the samples were determined by conventional methods. Sensory analysis was carried out by panel commission; the test included aroma, juiciness, palatability and tenderness on a 5-point scale (BaryłkoPikielna, 1975).

The materials were analyzed statistically by two-factorial analysis of variance in a non-orthogonal system. The significance of differences between the means for particular genetic groups of bulls and for the groups of muscles was defined with the Duncan and Student- $t$ tests. All calculations were performed using the SPSS program for Windows.

\section{RESULTS AND DISCUSSION}

\section{Physico-chemical properties of raw muscles}

Physico-chemical properties of raw LD and SM muscles of young bulls from the 4 experimental groups are presented in Table 1 . Meat colour determined $48 \mathrm{~h}$ after slaughter did not differ significantly among the particular bull groups. According to Wichłacz and Krzywicki (1986), the share of red meat colour depends on the myoglobin type and concentration, and more specifically, on the ratio between oxymyoglobin and myoglobin contents. The proper meat colour in young cattle, determined on an eight-point scale, should be between 4 and 5 points. Scores within this range were obtained only for SM muscle collected from young Black-and-White bulls. LD and SM muscle colour in other bull groups deviated with respect to its intensity from the proper one, with the LD muscle usually being darker than SM. Muscles of BW x A bulls were of the same colour, while in other bull crossbreeds the differences between these two muscles were statistically significant, $(\mathrm{P} \leq 0.01)$ in $\mathrm{BW} \times \mathrm{BB}$ group, and $(\mathrm{P} \leq 0.05)$ in $\mathrm{BW} \times \mathrm{Ch}$ bulls. As regards colour lightness, measured as the percent of rays reflected from a meat sample, the highest values (the lightest colour) were obtained for $\mathrm{BW} \times \mathrm{Ch}$ bulls, and the results for this group differed significantly $(\mathrm{P} \leq 0.01)$ from other groups. The results for colour intensity 
TABLE 1

Physico-chemical properties of raw meat

\begin{tabular}{|c|c|c|c|c|c|c|c|c|c|}
\hline \multirow{3}{*}{ Specification } & \multirow{3}{*}{ Muscle } & \multicolumn{8}{|c|}{ Groups } \\
\hline & & \multicolumn{2}{|c|}{$\mathrm{BW} \times \mathrm{BB}$} & \multicolumn{2}{|c|}{$\mathrm{BW} \times \mathrm{Ch}$} & \multicolumn{2}{|c|}{$\mathrm{BW} \times \mathrm{A}$} & \multicolumn{2}{|c|}{ BW } \\
\hline & & $\mathrm{X}$ & $\mathrm{V}$ & $\mathrm{X}$ & $\mathrm{V}$ & $\mathrm{X}$ & $\mathrm{V}$ & $\mathrm{X}$ & $\mathrm{V}$ \\
\hline \multirow{4}{*}{ Colour, $48 \mathrm{~h}$ after slaughter, points } & LD & $x \times 6.45$ & 11.63 & 6.33 & 11.85 & 5.64 & 15.07 & 5.67 & 31.39 \\
\hline & SM & 5.68 & 13.91 & 5.28 & 23.29 & 5.64 & 20.92 & 4.83 & 16.36 \\
\hline & Mean & $6.07^{a}$ & 14.17 & $5.80^{\text {ab }}$ & 19.48 & $5.64^{\text {itb }}$ & 17.55 & $5.25^{b}$ & 26.48 \\
\hline & LD & $10.28^{\mathrm{H}}$ & 27.53 & $13.55^{\mathrm{A}}$ & 15.20 & $9.75^{\mathrm{B}}$ & 9.13 & $9.22^{\mathrm{B}}$ & 11.82 \\
\hline \multirow[t]{3}{*}{ Colour lightness, $\%$} & SM & ${ }^{x \times} 12.60^{\mathrm{B}}$ & 17.85 & $16.55^{\wedge}$ & 24.71 & ${ }^{x \times} 12.25^{\mathrm{B}}$ & 14.28 & ${ }^{\mathrm{x}} 11.55^{\mathrm{B}}$ & 12.29 \\
\hline & Mean & $11.44^{\mathrm{B}}$ & 24.39 & $15.05^{\mathrm{A}}$ & 23.25 & $11.00^{\mathrm{B}}$ & 16.91 & $10.39^{\mathrm{B}}$ & 16.55 \\
\hline & LD & $\times 6.56^{\text {Aa }}$ & 5.64 & $6.03^{\mathrm{Bb}}$ & 8.95 & $6.13^{\mathrm{ABh}}$ & 6.52 & $6.53^{\mathrm{ABa}}$ & 5.67 \\
\hline \multirow{3}{*}{$\mathrm{pH}_{4 \times \mathrm{b}}$ value } & $\mathrm{SM}$ & $6.35^{\text {Aa }}$ & 4.88 & $5.88^{\mathrm{Bb}}$ & 7.31 & $6.24^{\mathrm{A} \mathrm{Ba}}$ & 7.85 & $6.42^{\mathrm{Aa}}$ & 5.29 \\
\hline & Mean & $6.46^{\text {Aiu }}$ & 5.57 & $5.95^{\mathrm{BC}}$ & 8.07 & $6.19^{\mathrm{ABc}}$ & 6.95 & $6.47^{\mathrm{Au}}$ & 5.41 \\
\hline & LD & ${ }^{\mathrm{x}} 1.41^{\mathrm{sb}}$ & 28.37 & $1.28^{\mathrm{b}}$ & 34.37 & $1.57^{\mathrm{ab}}$ & 38.85 & $1.78^{a}$ & 28.65 \\
\hline \multirow[t]{2}{*}{ Marbling, points } & $\mathrm{SM}$ & 1.18 & 20.34 & 1.39 & 30.21 & 1.28 & 30.47 & 1.39 & 23.74 \\
\hline & Mean & $1.29^{\mathrm{b}}$ & 27.13 & $1.33^{\mathrm{ab}}$ & 31.58 & $1.43^{\mathrm{ab}}$ & 35.66 & $1.58^{\mathrm{a}}$ & 29.11 \\
\hline \multirow{3}{*}{$\begin{array}{l}\text { Water absorption, with centrifuge } \\
\text { method, \% }\end{array}$} & LD & $59.67^{\mathrm{ABa}}$ & 40.29 & $31.92^{\mathrm{Eh}}$ & 81.80 & $44.72^{\mathrm{ABab}}$ & 78.06 & $64.98^{\mathrm{Aa}}$ & 31.10 \\
\hline & SM & $54.57^{\mathrm{a}}$ & 39.67 & $29.39^{b}$ & 104.66 & $40.64^{\mathrm{ab}}$ & 71.04 & $55.29^{3}$ & 47.48 \\
\hline & Mean & $57.12^{\text {Aab }}$ & 39.90 & $30.95^{\mathrm{BC}}$ & 88.37 & $42.68^{\text {ABbe }}$ & 71.44 & $60.14^{\wedge a}$ & 38.69 \\
\hline \multirow{3}{*}{$\begin{array}{l}\text { Water absorption acc. Grau } \\
\text { and Hamm, } \%\end{array}$} & LD & $3.49^{\mathrm{ab}}$ & 45.84 & $5.08^{\mathrm{a}}$ & 39.37 & $4.03^{\mathrm{ab}}$ & 57.57 & $2.90^{\mathrm{b}}$ & 37.24 \\
\hline & $\mathrm{SM}$ & $4.25^{A B b}$ & 30.35 & $6.16^{\mathrm{Aa}}$ & 35.39 & $4.92^{\mathrm{ABab}}$ & 46.34 & $3.95^{\mathrm{ph}}$ & 44.56 \\
\hline & Mean & $3.87^{\mathrm{Hb}}$ & 38.50 & $5.62^{\mathrm{Ad}}$ & 37.37 & $4.48^{A B b}$ & 50.67 & $3.43^{13 b}$ & 44.02 \\
\hline
\end{tabular}

$\mathrm{LD}-M$. longissimus dorsi; $\mathrm{SM}-M$. semitendinosus

$\mathrm{a}, \mathrm{b}-\mathrm{P} \leq 0.05 ; \mathrm{A}, \mathrm{B}-\mathrm{P} \leq 0.01$ (rows)

$\mathrm{x}-\mathrm{P} \leq 0.05 ; \mathrm{xx}-\mathrm{P} \leq 0.01$ (columns) 
and lightness were higher than those obtained by Mielnik (1990), Adamiak et al. (1996). Purchas et al. (1992) did not find significant differences in meat colour between Fresian bulls and Fresian x BB crossbreds, whereas Gerhardy (1994) and Schneijdenberg et al. (1994) reported lighter meat colour for crosses with beef breeds.

Average $\mathrm{pH}$ of the muscles was 5.95-6.47 and differed considerably between the experimental groups. The lowest $\mathrm{pH}$ values were noted for the meat of $\mathrm{BW} \times \mathrm{Ch}$ bulls, and were significantly $(\mathrm{P} \leq 0.01)$ different than in $\mathrm{BW} \times \mathrm{BB}$ and $\mathrm{BW}$ bulls. Also $\mathrm{BW} \times \mathrm{A}$ bulls differed significantly $(\mathrm{P} \leq 0.05)$ from the other experimental groups. Differences in $\mathrm{pH}$ values between $\mathrm{LD}$ and $\mathrm{SM}$ muscles were small and significant only in the $\mathrm{BW} \times \mathrm{BB}$ group $(\mathrm{P} \leq 0.05)$, in which $\mathrm{pH}$ was higher in $\mathrm{LD}$ than in SM muscles. Homer et al. (1997) did not find significant differences in $\mathrm{pH}$ values between crossbreeds of Belgian Blue and Charolaise.

Marbling degree, which reflects the content of intramuscular fat, was determined on a 5-point scale. Its values ranged between 1.29 and 1.58 , suggesting an inadequately low fat content. In their study, Wichłacz and Trela (1996) obtained a mean marbling of 2.11 points and stated that this value was insufficient. On the other hand, Armbuster et al. (1983) suggested that this trait is of little significance in assessing suitability of meat for consumption. Meat of BW bulls had the highest content of intramuscular fat, differing significantly $(\mathrm{P} \leq 0.05)$ from $\mathrm{BW} \times \mathrm{BB}$ crossbreeds. A significant $(\mathrm{P} \leq 0.05)$ difference was also observed with respect to marbling score in LD muscle of BW and BW $x$ Ch bulls. With the exception of the BW $x$ Ch group, LD muscles were usually more fatty than SM, and in the case of $\mathrm{BW} \times \mathrm{BB}$ crossbreeds, this difference was statistically significant $(\mathrm{P} \leq 0.05)$. Also Adamiak et al. (1996) observed the highest marbling score in LD muscle of Blackand-White bulls compared with the crosses with beef breeds.

Water absorption determined by the "centrifuge" method assesses the ability of meat to absorb water. Higher values of this index reflect higher water absorption ability. The results obtained with the discussed method revealed considerable differences among the bulls. Meat of Black-and-White and Black-and-White crossbreeds with $\mathrm{BB}$ proved to have the highest water absorption, while the lowest values were obtained for $\mathrm{BW} \times \mathrm{Ch}$ bulls. The difference between the latter group and those having the highest water absorption values was statistically significant ( $\mathrm{P} \leq 0.01$ ). LD muscle showed higher water absorption than SM in all bull groups, but the differences were not confirmed statistically due to exceptionally high variability. Lower water absorption ability in the case of crossbreeds with beef breeds compared with BW was also observed by Zalewski et al. (1991). On the other hand, studies by Mielnik (1990) showed that BW x Ch bulls were more satisfactory in this respect than BW bulls.

Water absorption determined by the method of Grau and Hamm measures the difference between the area of a stain made on blotting paper by meat juice leaking 
and area occupied by a meat sample. Higher values of this index reflect worse water absorption ability. Statistical analysis of the results obtained with this method confirmed the differences found with the "centrifuge" method.

\section{Chemical analyses of meat}

Dry matter content (Table 2) in bull meat was similar in all samples (22.6-23.3\%); there were no statistically significant differences between the experimental animal groups and between the muscles $(\mathrm{P}>0.05)$.

Fat content in meat was very low, from 0.56 to $1.38 \%$. Notwithstanding this and very high individual variability, it was found that the highest fat content in SM muscles of BW bulls differed significantly $(\mathrm{P} \leq 0.01)$ from the values found for $\mathrm{BW} \times \mathrm{BB}$ and $\mathrm{BW} \times \mathrm{Ch}$, as well as for $\mathrm{BW} \times \mathrm{A}(\mathrm{P} \leq 0.05)$. Wichłacz and Trela (1996) suggest that the minimal fat level in meat should not be lower than $1.5 \%$. Fat content in the meat of crossbreeds was lower than the values cited by Homer et al. (1997).

Crude protein content was within the range of $20.8-22.2 \%$ and differed only between the genetic groups. The highest levels of total protein were found for BW x BB bulls; meat of these animals also contained the highest levels of dry matter. Protein content in this group was significantly higher $(\mathrm{P} \leq 0.01)$ than in the meat of $\mathrm{BW} \times \mathrm{Ch}$ bulls, which contained the lowest protein levels. It was also significantly higher than in $\mathrm{BW}$ and $\mathrm{BW} \times \mathrm{A}$ bulls $(\mathrm{P} \leq 0.05)$. LD muscle contained more protein than SM in all bull groups, but these differences were not statistically significant. Total protein content in meat was characterized by low variability, so that variability coefficients (v) were low. The content of water-soluble proteins, consisting of myofibrils and sarcoplasm, is fairly important when shredded meat products are made (Tyszkiewicz and Tyszkiewicz, 1972). Very low and significantly different $(\mathrm{P} \leq 0.01)$ levels of this index were found in $\mathrm{BW} \times \mathrm{Ch}$ crossbreeds compared with the other three groups, particularly in the case of LD muscle. Although LD muscle contained more proteins than SM in all genetic groups, the differences were not statistically significant $(\mathrm{P}>0.05)$. Gerhardy (1994) found higher protein contents in meat than in this study, but Mielnik (1990) obtained lower values. Ash content was the lowest in the meat of BW x BB bulls, in which it was significantly different $(\mathrm{P} \leq 0.05)$ than in $\mathrm{BW} \times \mathrm{Ch}$ and $\mathrm{BW} \times \mathrm{A}$ bulls. SM muscle contained slightly more ash than $\mathrm{LD}$ in all groups.

\section{Sensoric properties of meat}

Mean values of each analyzed sensoric parameters exceeded 4 points, suggesting very high quality of the meat (Table 3 ). The genotype of the bulls proved to determine sensoric properties the meat. Meat of $\mathrm{BW} \times \mathrm{BB}$ bulls was assessed as 
TABLE 2

Chemical composition of young bull meat, \%

\begin{tabular}{|c|c|c|c|c|c|c|c|c|c|c|}
\hline \multirow{3}{*}{ Specification } & & \multirow{3}{*}{ Muscle $^{1}$} & \multicolumn{8}{|c|}{ Groups } \\
\hline & & & \multicolumn{2}{|c|}{$\mathrm{BW} \times \mathrm{BB}$} & \multicolumn{2}{|c|}{$\mathrm{BW} \times \mathrm{Ch}$} & \multicolumn{2}{|c|}{$\mathrm{BW} \times \mathrm{A}$} & \multicolumn{2}{|c|}{ BW } \\
\hline & & & $\mathrm{X}$ & $\mathrm{V}$ & $\mathrm{X}$ & $\mathrm{V}$ & $X$ & $\mathrm{~V}$ & $\mathrm{X}$ & $\mathrm{V}$ \\
\hline & & LD & 23.26 & 4.43 & 22.78 & 3.34 & 22.95 & 5.18 & 23.01 & 4.65 \\
\hline \multirow[t]{3}{*}{ Dry matter } & & SM & 23.05 & 3.69 & 22.74 & 2.37 & 22.65 & 3.35 & 23.14 & 5.44 \\
\hline & & Mean & 23.16 & 4.06 & 22.76 & 2.81 & 22.80 & 4.30 & 23.07 & 4.90 \\
\hline & & LD & 0.63 & 63.49 & 0.91 & 42.86 & 1.04 & 40.38 & 0.99 & 52.52 \\
\hline \multirow[t]{3}{*}{ Fat } & & $\mathrm{SM}$ & $0.56^{\mathrm{Bb}}$ & 82.14 & $0.83^{\mathrm{ABb}}$ & 48.19 & $0.72^{\mathrm{ABb}}$ & 29.17 & $1.38^{\mathrm{Aa}}$ & 84.78 \\
\hline & & Mean & $0.60^{\mathrm{B}}$ & 71.67 & $0.87^{\mathrm{AB}}$ & 43.68 & $0.88^{\mathrm{AB}}$ & 40.91 & $1.18^{\mathrm{A}}$ & 77.12 \\
\hline & & LD & $22.24^{a}$ & 6.47 & $21.00^{\mathrm{b}}$ & 3.95 & $21.38^{\mathrm{ab}}$ & 4.96 & $21.30^{\mathrm{ab}}$ & 3.43 \\
\hline \multirow[t]{3}{*}{ Crude protein } & & $\mathrm{SM}$ & 21.65 & 6.60 & 20.80 & 2.88 & 20.92 & 3.30 & 20.96 & 4.25 \\
\hline & & Mean & $21.94^{\mathrm{Aa}}$ & 6.61 & $20.90^{\mathrm{Bb}}$ & 3.40 & $21.15^{\mathrm{ABb}}$ & 4.25 & $21.13^{\mathrm{ABb}}$ & 3.83 \\
\hline & & LD & $7.09^{A}$ & 13.68 & $6.11^{\mathrm{B}}$ & 20.78 & $7.04^{\mathrm{A}}$ & 11.22 & $7.24^{\mathrm{A}}$ & 11.60 \\
\hline \multirow[t]{2}{*}{ Water-soluble protein } & & $\mathrm{SM}$ & 6.83 & 13.62 & 5.63 & 16.16 & 6.34 & 13.88 & 6.25 & 19.20 \\
\hline & & Mean & $6.96^{\mathrm{B}}$ & 13.65 & $5.87^{\mathrm{B}}$ & 17.89 & $6.69^{A}$ & 13.34 & $6.75^{\mathrm{A}}$ & 16.74 \\
\hline LD & & 1.09 & 7.34 & 1.13 & 4.42 & 1.14 & 3.51 & 1.10 & 7.27 & \\
\hline \multirow[t]{2}{*}{ Ash } & & SM & 1.13 & 5.31 & 1.18 & 3.39 & 1.17 & 6.84 & 1.13 & 10.64 \\
\hline & & Mean & $1.11^{\mathrm{b}}$ & 6.31 & $1.16^{\mathrm{a}}$ & 4.31 & $1.16^{\mathrm{a}}$ & 5.17 & $1.12^{\mathrm{ab}}$ & 8.03 \\
\hline
\end{tabular}

${ }^{1}$ see Table 1

$\mathrm{a}, \mathrm{b}-\mathrm{P} \leq 0.05 ; \mathrm{A}, \mathrm{B}-\mathrm{P} \leq 0.01$ (rows) 
TABLE 3

Sensoric properties of meat

\begin{tabular}{|c|c|c|c|c|c|c|c|c|c|}
\hline \multirow{3}{*}{ Specification } & \multirow{3}{*}{ Muscle' } & \multicolumn{8}{|c|}{ Groups } \\
\hline & & \multicolumn{2}{|c|}{$\mathrm{BW} \times \mathrm{BB}$} & \multicolumn{2}{|c|}{$\mathrm{BW} \times \mathrm{Ch}$} & \multicolumn{2}{|c|}{$\mathrm{BW} \times \mathrm{A}$} & \multicolumn{2}{|c|}{ BW } \\
\hline & & $\mathrm{X}$ & $\mathrm{V}$ & $X$ & $\mathrm{~V}$ & $\mathrm{X}$ & $\mathrm{V}$ & $\mathrm{X}$ & $\mathrm{V}$ \\
\hline & LD & 4.92 & 5.69 & 4.88 & 6.76 & 4.62 & 11.25 & 4.78 & 9.20 \\
\hline \multirow[t]{3}{*}{ Aroma, intensity, points } & SM & 4.92 & 5.69 & 4.72 & 7.63 & 4.87 & 7.19 & 4.72 & 9.32 \\
\hline & Mean & 4.92 & 5.49 & 4.80 & 7.29 & 4.75 & 9.26 & 4.75 & 9.05 \\
\hline & LD & 4.94 & 4.45 & 4.50 & 12.44 & 4.69 & 9.81 & 4.72 & 7.63 \\
\hline \multirow[t]{3}{*}{ Aroma, desirability, points } & SM & 4.88 & 6.15 & 4.61 & 9.11 & 4.69 & 7.89 & 4.67 & 7.49 \\
\hline & Mean & $4.91^{\mathrm{Aa}}$ & 5.29 & $4.55^{\mathrm{Hb}}$ & 19.55 & $4.69^{\mathrm{ABb}}$ & 8.53 & $4.69^{\mathrm{ABb}}$ & 7.46 \\
\hline & LD & 4.80 & 7.92 & 4.17 & 20.86 & 4.62 & 11.25 & 4.78 & 7.53 \\
\hline \multirow[t]{3}{*}{ Juiciness, points } & SM & 4.74 & 8.02 & 4.39 & 14.71 & 4.56 & 10.74 & 4.55 & 11.65 \\
\hline & Mean & $4.77^{\mathrm{Aa}}$ & 7.97 & $4.28^{\mathrm{Bb}}$ & 17.52 & $4.59^{\mathrm{ABa}}$ & 10.67 & $4.67^{\mathrm{ABa}}$ & 9.63 \\
\hline & LD & 4.78 & 7.32 & 4.17 & 20.86 & 4.37 & 15.78 & 4.78 & 7.53 \\
\hline \multirow[t]{3}{*}{ Palatability, intensity, points } & SM & 4.74 & 8.02 & 4.39 & 14.81 & 4.56 & 10.74 & 4.67 & 9.21 \\
\hline & Mean & $4.76^{\mathrm{Aa}}$ & 7.77 & $4.28^{\mathrm{Bb}}$ & 17.52 & $4.47^{\text {Aaab }}$ & 13.20 & $4.72^{\mathrm{ABa}}$ & 8.26 \\
\hline & LD & 4.80 & 7.92 & 4.17 & 20.86 & 4.56 & 10.74 & 4.67 & 9.21 \\
\hline \multirow[t]{3}{*}{ Palatability, desirability, points } & $\mathrm{SM}$ & 4.72 & 8.05 & 4.39 & 14.81 & 4.56 & 10.74 & 4.55 & 11.65 \\
\hline & Mean & $4.76^{\mathrm{Aa}}$ & 7.98 & $4.28^{\mathrm{Bb}}$ & 17.52 & $4.56^{\mathrm{ABab}}$ & 10.53 & $4.61^{\mathrm{ABa}}$ & 21.67 \\
\hline & LD & 4.68 & 8.55 & 4.11 & 21.65 & 4.25 & 15.29 & 4.72 & 10.30 \\
\hline \multirow[t]{2}{*}{ Tenderness, points } & $\mathrm{SM}$ & 4.58 & 9.17 & 4.28 & 13.08 & 4.56 & 10.74 & 4.55 & 12.75 \\
\hline & Mean & $4.63^{\mathrm{A}}$ & 8.85 & $4.19^{\mathrm{B}}$ & 17.42 & $4.40^{\mathrm{AB}}$ & 13.18 & $4.64^{\wedge}$ & 10.99 \\
\hline Overall sensoric value, points & & $4.79^{\mathrm{a}}$ & 4.79 & $4.40^{\mathrm{b}}$ & 11.82 & $4.48^{\mathrm{ab}}$ & 6.33 & $4.68^{\mathrm{ab}}$ & 6.41 \\
\hline
\end{tabular}

1 see Table 1

$\mathrm{a}, \mathrm{b}-\mathrm{P} \leq 0.05 ; \mathrm{A}, \mathrm{B}-\mathrm{P} \leq 0.01$ (rows) 
the best, tenderness being the only exception. This meat differed significantly $(\mathrm{P} \leq 0.01)$ with respect to aroma desirability, juiciness, palatability and tenderness from the meat of $\mathrm{BW} \times \mathrm{Ch}$ bulls, which was graded as the worst. Aroma desirability was also significantly $(\mathrm{P} \leq 0.05)$ higher in the meat of $\mathrm{BW} \times \mathrm{BB}$ bulls compared with $\mathrm{BW}$ and $\mathrm{BW} \times \mathrm{A}$ bulls. Meat of $\mathrm{BW} \times \mathrm{Ch}$ bulls, estimated as being of the poorest quality, differed significantly $(\mathrm{P} \leq 0.05)$ in terms of its juiciness from the meat of BW x A and BW bulls, and, as regards palatability and tenderness, from $\mathrm{BW}$ bulls $(\mathrm{P} \leq 0.01)$. Also mean sensoric parameters suggest that the meat of BW $\times$ BB crossbreeds was the most desirable, while the lowest appraisal was obtained for the meat of crossbreeds with Charolaise. Homer et al. (1997) also found significant differences in meat tenderness between crossbreeds with $\mathrm{BB}$ and those with Charolaise and Angus. However, the results do not always conform to those obtained by other authors - Litwińczuk (1989) and Zalewski et al. (1991) obtained higher sensoric parameters of the meat of BW bulls compared with crossbreeds. Schneijdenberg et al. (1994) also observed higher juiciness of the meat of MRY bulls compared to their crossbreeds with BB. On the other hand, Otto and Stang (1975) stated that meat of crossbreeds with beef breeds was more tender than of BW cattle. The worst estimate of meat tenderness obtained in this study for BW x Ch bulls can be explained by the most intensive contraction of muscle fibres during thermal processing of this meat (Lewis et al., 1977).

\section{Physico-chemical properties of processed meat}

Statistical analysis revealed a significant effect of the genetic group on cutting force, which reflects meat tenderness (Table 4). Tenderness assessed with this method confirmed the sensoric estimates. Meat of BW x Ch bulls was the least tender (the highest cutting force); it differed significantly ( $\mathrm{P} \leq 0.01)$ from $\mathrm{BW} \times \mathrm{BB}$ crossbreeds and BW bulls. A significant difference $(P \leq 0.01)$ was also found in meat tenderness between BW x A and BW bulls, the meat of which proved to be the most tender. Although LD muscle was more tender than SM in all groups, the differences were not statistically significant. The very high values of variability coefficients for this parameter, ranging from 23 to $64 \%$, are noteworthy. They suggest high individual variability, but also a possibility that estimation of meat tenderness with this method is not too accurate.

Weight losses during thermal processing were related to water absorption capacity. The same was found by Goszczyński et al. (1981), Mielnik et al. (1982) and Ziemiński et al. (1982). Meat of BW x Ch bulls, which was characterized by the lowest water absorption, was also characterized by the highest thermal drip, an undesirable property. This meat also displayed the highest shrinkage, resulting in low tenderness and the highest roasting losses. The differences between $\mathrm{BW} \times \mathrm{Ch}$ bulls and bulls from other groups were statistically significant $(\mathrm{P} \leq 0.01)$. Meat los- 
Physico-chemical properties of meat after thermal processing

TABLE 4

忌

Muscle ${ }^{1}$

Specification

Groups

$+2$

cutting force, $\mathrm{N}$

$\begin{array}{ccc} & \mathrm{X} & \mathrm{V} \\ \mathrm{LD} & 52.32 & 64.14\end{array}$

$\begin{array}{lll}\mathrm{SM} & 43.28 \quad 56.06\end{array}$

Mean $\quad 47.80^{\mathrm{BCb}} \quad 59.96$

LD $\quad 24.88^{\text {ab }} \quad 21.32$

$\begin{array}{lll}\text { SM } & 26.14^{\mathrm{Bb}} & 17.52\end{array}$

Mean $\quad 25.51^{\mathrm{Bb}} \quad 19.68$

19.68

$\begin{array}{lll}\text { LD } & 26.89^{\mathrm{B}} & 19.49\end{array}$

SM $\quad \times 30.67^{\mathrm{Bb}} \quad 20.61$

$\begin{array}{lll}\text { Mean } & 28.78^{\mathrm{Bc}} & 21.61\end{array}$

$\begin{array}{lll}\text { LD } & 32.13^{\mathrm{B}} & 15.65\end{array}$

$\begin{array}{lll}\mathrm{SM} & 30.75^{\mathrm{B}} & 17.36\end{array}$

$\begin{array}{lll}\text { Mean } \quad 31.44^{\mathrm{B}} \quad 16.51 & \end{array}$

$6.51 \quad 41.47^{\mathrm{A}}$

89.92
68.21
$79.07^{\mathrm{Aa}}$
$29.32^{\mathrm{a}}$
$33.26^{\mathrm{Aa}}$
$31.29^{\mathrm{Aa}}$
$37.92^{\mathrm{A}}$
$41.35^{\mathrm{Aa}}$
$39.64^{\mathrm{Aa}}$
$42.43^{\mathrm{A}}$
$40.52^{\mathrm{A}}$
$41.47^{\mathrm{A}}$

' see Table 1

$\mathrm{a}, \mathrm{b}-\mathrm{P} \leq 0.05 ; \mathrm{A}, \mathrm{B}-\mathrm{P} \leq 0.01$ (rows)

$\mathrm{X}-\mathrm{P} \leq 0.05$ (columns) 
ses during roasting in $\mathrm{BW}$ bulls were similar to those obtained by Clinquart et al. (1994) during meat cooking, but these losses were much higher than those given by these authors for BB cattle.

\section{CONCLUSIONS}

Bull genotype significantly affects meat quality, but quality estimates were diversified when related to physico-chemical parameters, nutrient content or sensoric parameters.

The results of sensoric evaluation suggest that bulls crossbred with Belgian Blue cattle are characterized by meat most suitable for cooking.

Physico-chemical properties of meat after thermal processing as well as sensoric parameters showed that meat of $\mathrm{BW} \times \mathrm{Ch}$ bulls was the least suitable for cooking purposes.

\section{REFERENCES}

Adamiak P., Trela J., Czaja H., 1996. Slaughter value of commercial crossbreds (in Polish). Zesz. Nauk. AR Wrocław, 291, 255-262

Armbruster G., Nour A.Y.M., Thonney M.L., Stouffer J.R., 1983. Changes in cooking losses and sensory attributes of Angus and Holstein beef with increasing carcass weight, marbling score or Longissimus ether extract. J. Food Sci. 48, 835-840

Baryłko-Pikielna N., 1975. An Outline of Sensoric Food Analyses (in Polish). WTN, Warszawa

Clinquart A., Van Eaname C., Van Vooren T., Van Hoof J., Hornick J.I., 1994. Meat quality in relation to breed ( Belgian Blue vs. Holstein) and conformation (double muscled vs. dual purpose). Sci. Aliment. 14, 401-407

Gerhardy H., 1994. A study of marked-oriented beef production with Black Pied bulls and crosses with Simmental, Limousin and Belgian Blue and White crossbreds. Züchtungskunde 66, $281-296$

Goszczyński J., Mielnik J., Stambrowski M., Chartanowicz W., 1981. Slaughter value and quality of yearling bull crossbreds of Black-White cows $x$ Charolais and of Hereford and Charolais yearling bulls. II. Physico-chemical and palatable properties of lean from crossbreds (in Polish). Zesz. nauk. ART Olszt., Zoot. 21, 115-125

Homer D.B., Cuthbertson A., Homer D.L.M., McMenamin P., 1987. Eating quality of beef from different sire breeds. Anim. Sci. 64, 403-408

Lewis P.K.Jr., Brown C.J., Heck M. C., 1977. Fiber diameter, sarcomere length and tenderness of certain muscles crossbred beef steers. J. Anim. Sci. 45, 254-260

Litwińczuk Z., 1989. Schlachtleistung und physikalisch-chemische Qualität vom Fleisch den Schwarzweissjungbullen und verschiedenen Kreuzungen mit Füttenung aus Dauer-grünland (in Polish). Proceedings of Conference „Cattle Breeding and Directions of Improving Cattle Production on Natural Pastures". Pawłowice (Poland), pp. 84-93 
Mielnik J., 1990. Studies on dairy and meat use of 4-breed (BW, DR, BR, J) and 2-breed (BW, CH) crosses compared with Black-White varicty (in Polish). Acta. Acad. Agric. Tech. Olst., Zoot. 33, Suppl. A, 1-57

Mielnik J., Sobina I., Meller Z., Rydzik W., Stambrowski M., 1982. Factors determining meat colour (in Polish). Post. Nauk rol. 29 (1-2), 63-76

Otto E., Stang N., 1975. Über die Zartheit bei Rindfleisch. Fleisch 7, 137-138

Purchas R., Morris S., Grant D., 1992. A comparision of characteristics of carcasses Friesian, Piedmontese x Fresian and Belgian Blue x Fresian bulls. NZJ. Agric. Res. 35, 401-409

Schneijdenberg T., Hoving-Bolink A., De Vries A., Vonder G., Merkus G., 1994. Rapport Institut voor Veehouderij en Diergezondheid Dienst Landbouwkundig Onderzoek. 383, pp. 30

Tyszkiewicz I., Tyszkiewicz S., 1972. Selected basic problems of meat sciences. Meat proteins (in Polish). Gosp. Mięs. 24 (3), 20-25

Wichłacz H., Krzywicki K., 1986. Meat colouring (in Polish). Gosp. Mięs. 38 (2), 16-18

Wichłacz H., Trela J., 1996. The meat quality of experimental cattle (in Polish). Proceedings of Conference "Achivements and Prospects of Studies of BeefC Cattle Breed. Popielno (Poland), pp. 147-151

Zalewski W., Kamieniecki K., Jasińska E., Szwarc B., 1991. Indices of beef performance and taste panel evaluation of meat from Black and White cows and after Simmental and Limousin bulls (in Polish). Prz. hod., Zesz. Nauk. No 3, Cattle Production and Breeding, 239-244

Ziemiński R., Górska I., Szmańko T., Krasnowska G., 1982. The evaluation of the chosen parameters of meat quality in cross-breeds Piemontese x Red-Pied and Blonde D'Aquitaine $x$ Red-Pied (in Polish). Rocz. Nauk. Zoot. 20, 93-104

Znaniecki P., 1983. A Review of the Supply, Assessment and Processing of Animal Products (in Polish). PWRiL, Warszawa

\section{STRESZCZENIE}

\section{Porównanie jakości mięsa buhajków rasy czarno-bialej i jej mieszańców z rasami mięsnymi}

Oceniono jakość mięsa 3 grup buhajków mieszańców $\mathrm{F}_{1}$ pochodzących od krów rasy czarnobiałej z dolewem 12,5-50\% krwi rasy holsztyńsko-fryzyjskiej i po buhajach ras mięsnych: belgijskiej biało-błękitncj (BW x BB) - 25 szt., charolaise (BW x Ch) -9 szt. i angus (BW x A) - 8 szt. w porównaniu z jakością mięsa rówieśników rasy czarno-białej $(B W)-9$. Opas buhajków trwał od 6 do 20 micsiąca życia. Stosowano pólintensywne żywienie grupowe zadając dawkę złożoną z kiszonki z kukurydzy, $1 \mathrm{~kg}$ siana łąkowego oraz paszy treściwej, przy założeniu przyrostów około $800 \mathrm{~g}$ na dobę.

Ocenę mięsa wykonano na próbkach pobranych z mięsnia najdłuższego grzbietu (LD) i miesnia półścięgnistego uda (SM). Oceniono właściwosci fizykochemiczne, cechy sensoryczne oraz skad chemiczny miesa. Stwierdzono, że na jakość mięsa miał zdecydowany wpływ genotyp buhajków, a w niektórych przypadkach także rodzaj ocenianego miesśnia. Analiza wszystkich cech jakości mięsa nie pozwala na jednoznaczne wskazanie grupy buhajków, której mięso najbardziej nadaje się do celów kulinarnych. Wyniki oceny sensorycznej preferują jednak na te cele mięso buhajków mieszanców rasy czarno-białcj z rasą bclgijską biało-błękitną. 